\title{
THE CHEMICAL COMPOSITION AND INDUSTRIAL QUALITY OF BARITE MINERALIZATION IN CALABAR FLANK, OBAN MASSIF, MAMFE EMBAYMENT AND OBUDU PLATEAU, SOUTHEASTERN NIGERIA
}

BARTH N. EKWUEME, GABRIEL B. AKPEKE AND BASSEY E. EPHRAIM

(Received 30 October 2012; Revision Accepted 23 May 2013)

\begin{abstract}
Barite occurrences in the Calabar Flank, Oban massif, Mamfe Embayment and Obudu Plateau of Southeastern Nigeria have been sampled and analyzed for the purpose of assessing their chemical composition and industrial quality. Barite occurrences were observed mostly along faults and unconformities marking the boundaries between the Precambrian basement rocks of Oban and Obudu massifs and the Cretaceous sediments of the Calabar Flank and Mamfe embayment. Occurrences were also observed within the sediments. The chemical data show that $\mathrm{BaSO}_{4}, \mathrm{SiO}_{2}$ and $\mathrm{TiO}_{2}$ are the major chemical species of the barite. The $\mathrm{Ba}$ and $\mathrm{SO}_{4}$ content vary between $53.62-$ $56.10 \mathrm{wt} \%$ and $27.57-39.35 \mathrm{wt} \%$ respectively across the sampled areas. The specific gravity is 4.45 and this combined with high $\mathrm{BaSO}_{4}$ (approximately $94 \mathrm{wt} \%$ ) shows that the mineralization is of high industrial quality and compares favourably with the Azara barite deposits of the Benue Trough. The quality of the barite meets American Petroleum institute (API) requirements for use as drilling mud.
\end{abstract}

KEYWORDS: Barite, mineralization, quality, chemical composition, southeastern Nigeria.

\section{INTRODUCTION}

A typical barite sample is expected to have $65.70 \%$ and $34.30 \%$ of the element Barium and $\left(\mathrm{SO}_{4}\right)^{2-}$ respectively (Krauskopf and Beiser 1986). Barite has a specific gravity (SG) of 4.5 in pure state and is often referred to as 'heavy spar'. A high density, chemical inertness and widespread occurrence are the properties that are valued for barites application as a weighting agent in drilling fluids. Colour and chemical purity are important properties when considering the suitability of barite for non-drilling applications. Barite has various uses. For instance, high purity grades of barite with fine and well-sorted particles are used as fillers in marine and industrial paints, in brake lining/friction materials and in plastics.

A specialized use of barite based on its high density and ability to absorb radiation is as an aggregate in dense concrete for shielding applications in the nuclear industry and hospital radiation departments. For barite to be used in the non-petroleum industries, it needs to undergo processing through beneficiation methods such as washing, jigging, heavy metal separation, tabling, floatation and magnetic separation. Most crude barite requires some upgrading to minimum priority of density.

The texture and size distribution of various species of gangue minerals affect the beneficiation of barite. Petrographic examination of barite specimens is very vital in this beneficiation process.

There have been speculations that barites occur in many parts of Cross River State of Nigeria. There have also been attempts to mine barites in some parts of the state using "trial and error" method.

This study was undertaken to geologically map the host rocks and the barite deposits, and determine their relationship with other rocks in the area. It is also the aim of this study to carry out a detailed petrographic and geochemical analysis of these barites to determine their suitability for industrial use.

Barth N. Ekwueme, Department of Geology, University of Calabar, P. O. Box 3651 Unical P. O. Calabar, Nigeria

Gabriel B. Akpeke, Department of Geology, University of Calabar, Calabar, Nigeria

Bassey E. Ephraim, Department of Geology, University of Calabar, Calabar, Nigeria 


\section{GEOLOGICAL SETTING}

The geology of southeastern Nigeria consists of two Precambrian basement spurs the Oban massif and the Obudu Plateau. These basement horsts are unconformably overlain by the Cretaceous sedimentary rocks of the Calabar Flank and Ikom-Mamfe embayment (Fig. 1). The barite deposits analyzed in this study occur dominantly along the unconformities and faults at the basement/sedimentary rock boundaries. Some barite deposits also occur within the sedimentary terrains. The two basement horsts are separated by the Mamfe rift. Bassey (1998) had suggested that the Oban massif and the Obudu Plateau could have been a contiguous block prior to the formation of the Mamfe basin. Cretaceous sediments of the Calabar Flank overlie the Oban massif whilst those of the Mamfe basin overlie the Obudu Plateau.

A dolerite dyke intruding the Precambrian rocks in Obudu Plateau yielded an ${ }^{40} \mathrm{Ar} /{ }^{39} \mathrm{Ar}$ plateau age of 140 $\pm 0.7 \mathrm{Ma}$ (Ekwueme 1994a) whilst zircons extracted from the basement rocks (gneisses and schists) of Obudu gave ages of 2062.4 $\pm 0.4 \mathrm{Ma}$ (Palaeoproterozoic) and 2,504.5 $\pm 0.5 \mathrm{Ma}$ (NeoArchaean) (Ekwueme and Kroener 1997, 2006, Kalsbeek et al. 2013). The gneisses in the basement of Oban massif gave Zircon ages of 1931.9 $\pm 0.8 \mathrm{Ma}$ (Palaeoproterozoic) (Ekwueme and Kroener 1998).

The basement rocks have undergone polyphase deformation and polymetamorphism resulting in several generations of folding faulting, shearing and fracturing as reported by Ekwueme (1987, 1994b). The dominant trend of these structures is N-S to NE-SW $\left(0-30^{\circ}\right)$ indicative of Pan-African deformation (Onyeagocha and Ekwueme 1982, Ekwueme 1987).

The Calabar Flank is in the southern (Lower) Benue Trough. The oldest sedimentary rock in the Calabar Flank is Awi Formation of Aptian-Albian age (Adeleye and Fayose 1978). It lies unconformably on the Precambrian basement rock of Oban massif. Overlying the Awi Formation is the Mfamosing Limestone Formation of Petters (1982), which is in turn overlain by the Eze-Aku Shale of Reyment (1965), later described by Petters et al. (2010) as Ekenkpon Shales. Associated with these shales are bioturbated marls which are overlain by Nkporo Shale of Campanian-Maastritchian ages. The youngest formation in the Calabar Flank is the unconsolidated sand belonging to the Benin Formation of Tertiary age.

The Mamfe Embayment is predominantly a fluviatile clastic sequence that exhibits point bar fining upward cycles and over bank mudrocks (Ekwueme et al. 1995). This formation has been described as the Asu River Group of Albian age. Associated with the sedimentary rocks of Mamfe rift are basaltic rocks which exhibit excellent columnar joints (Ekwueme 2012). Type locality of the Mamfe Formation is on the bank of the Cross River at Mamfe in adjoining Cameroon Republic where $800 \mathrm{~m}$ of massive arkosic sandstones with marl, sandy limestone and shale intercatations are exposed (Reyment 1965). The sequence in the Nigerian part of the Mamfe Basin comprises conglomeritic immature mudstones (Petters et al. 1987). The Mamfe Formation lies unconformably on the Precambrian basement of the Obudu Plateau.

\section{FIELD OCCURRENCE AND DISTRIBUTION OF BARITE}

As observed by mining geologist, mainly unconformities and major faults are well exposed during mining operations as features that host barite ore in the study area. The Mamfe rift and the Calabar Flank belong to the lower Benue Trough. The Trough is a geosynclinal structure; and as expected in such regions, accumulation of sediments was followed by uplifting, folding and faulting (Benkhelil 1987). The effects of these stresses created unconformities at the boundary between the basement and the deposited sediments, and faults within the folded sediments. Hence, barite was accumulated in major faults within the carbonaceous shales, limestones, siltstone and calcareous sandstone (of the Cross River and Asu River Groups within the lower Benue Trough) and along the basement-sediments boundary. Hence, these locations were geologically mapped in detail to delineate the ores. This is evident in the location of barite vein within a generalized stratigraphic section at Agoi Ibiami (Fig. 2), within sediments (Fig. 3) and in dolerite dykes along the basement boundary (Fig. 4). It is possible that the mineralization episodes were in pulses in basements, cross-cutting intrusives and in sediments. The reactive calcareous nature of the sandstone helped in the formation of the mineral while the high permeability within the sandstones and shales allowed the localization of the mineralizing fluids in the area. The mineralized veins are generally observed to trend NESW (Fig. 5). Oden (2012) recognized barite veins trending N-S and NW-SE in the Benue Trough. He considered these veins older than other veins and more frequent. According to him the vein sets were formed from tension joints reflecting different post-sedimentary deformation phases in the trough. The dips of the veins are near vertical to vertical $\left(80^{\circ}\right.$ to $90^{\circ}$ ). The largest veins are in Gabu-Osina area and these veins are up to $2 \mathrm{~km}$ in length. These veins were mapped in this study and the barite ores were characterized using detailed petrographic and geochemical analyses followed by rigorous interpretations. 


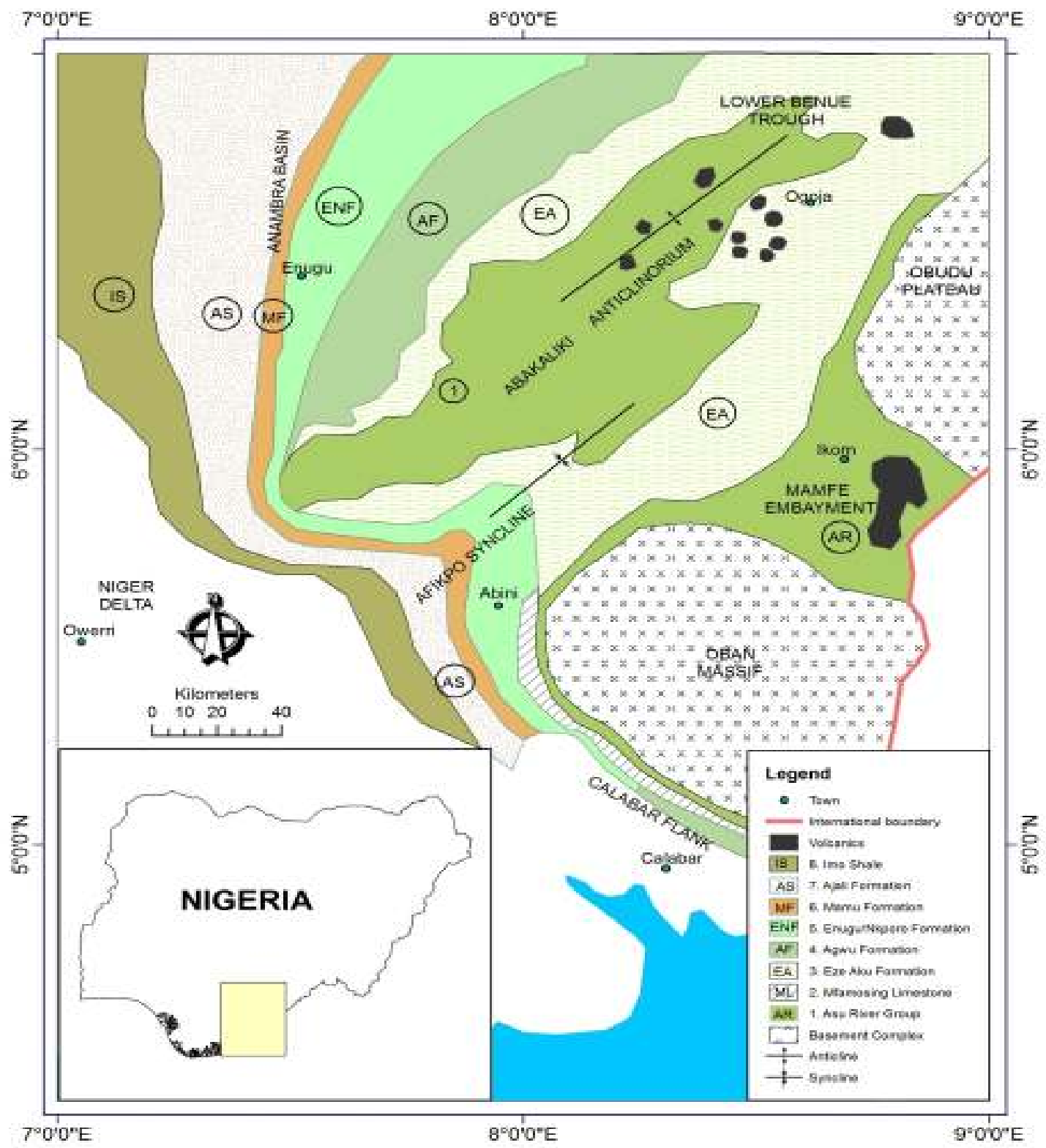

Fig 1: Geologic sketch map of Southeastern Nigeria (After Ekwueme et al. 1995) 


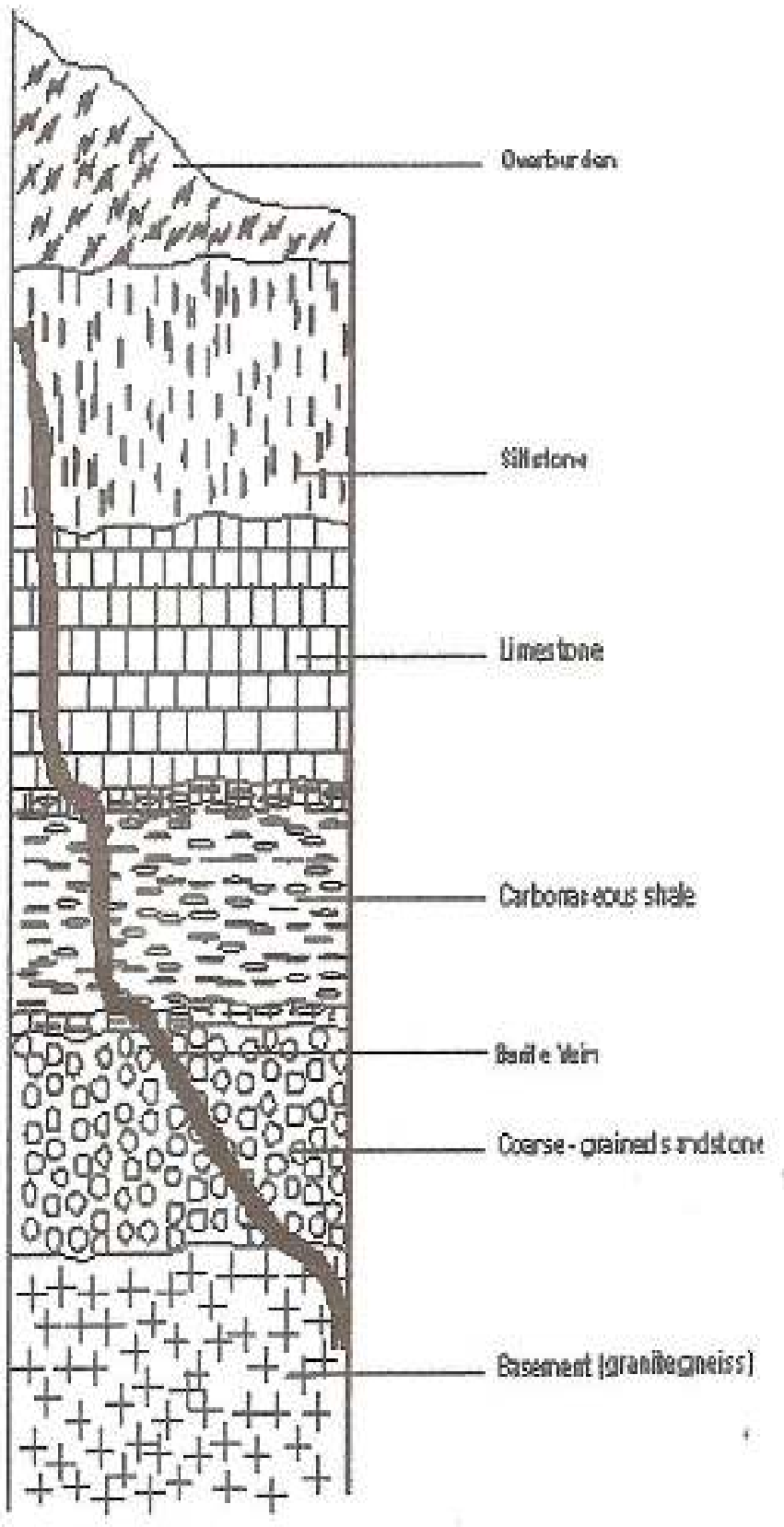

Fig 2: Location of barite vein in a generalized stratigraphic chart at Agoi Ibami $\left(05^{0} 43^{\prime} 27^{\prime \prime} \mathrm{N}, 08^{0} 12^{\prime} 22^{\prime \prime} \mathrm{E}\right)$

$050 \mathrm{~m}$ Barite Length 


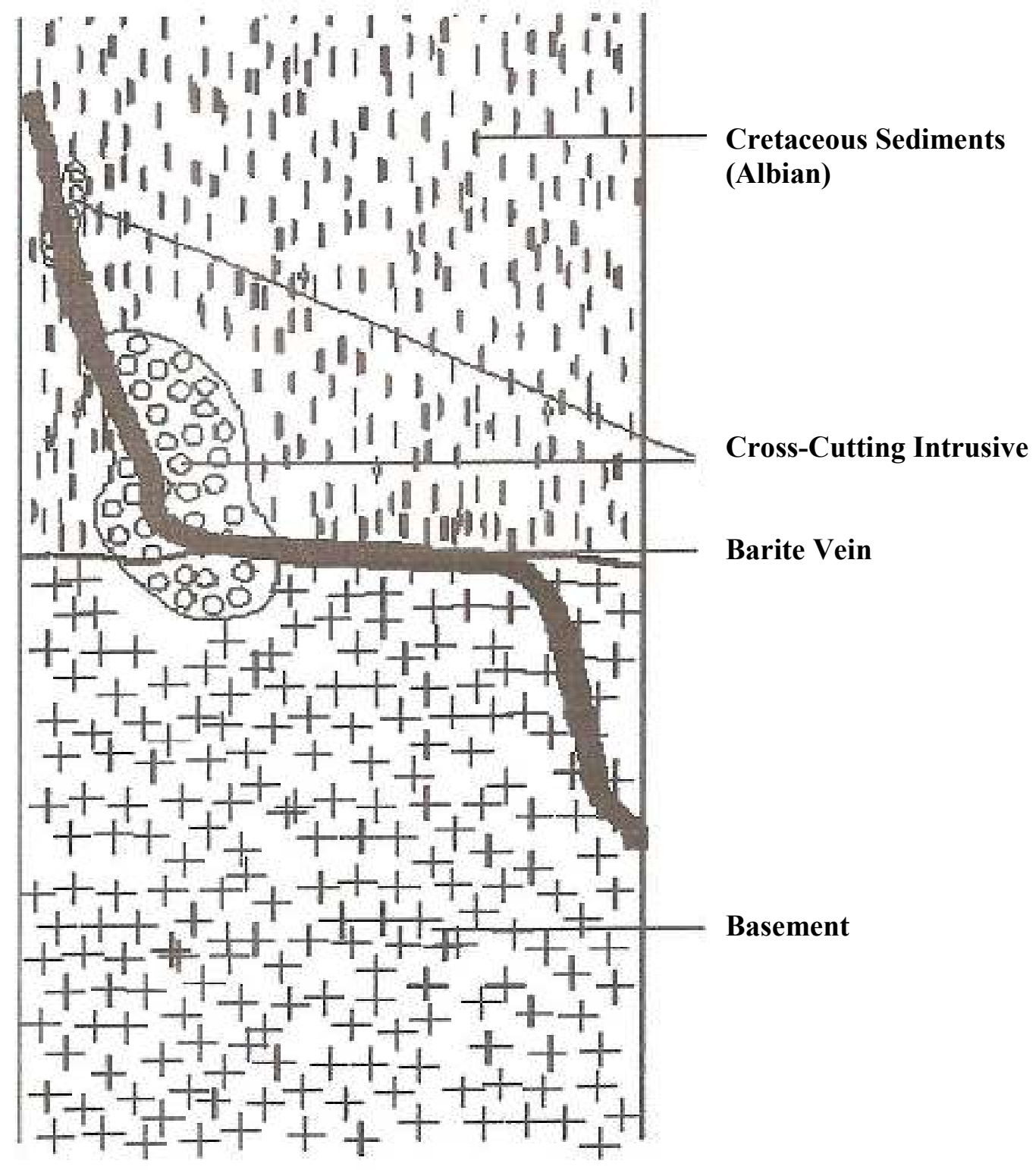

Fig 3: Generalized model of Barite Mineralization in Cross River State 


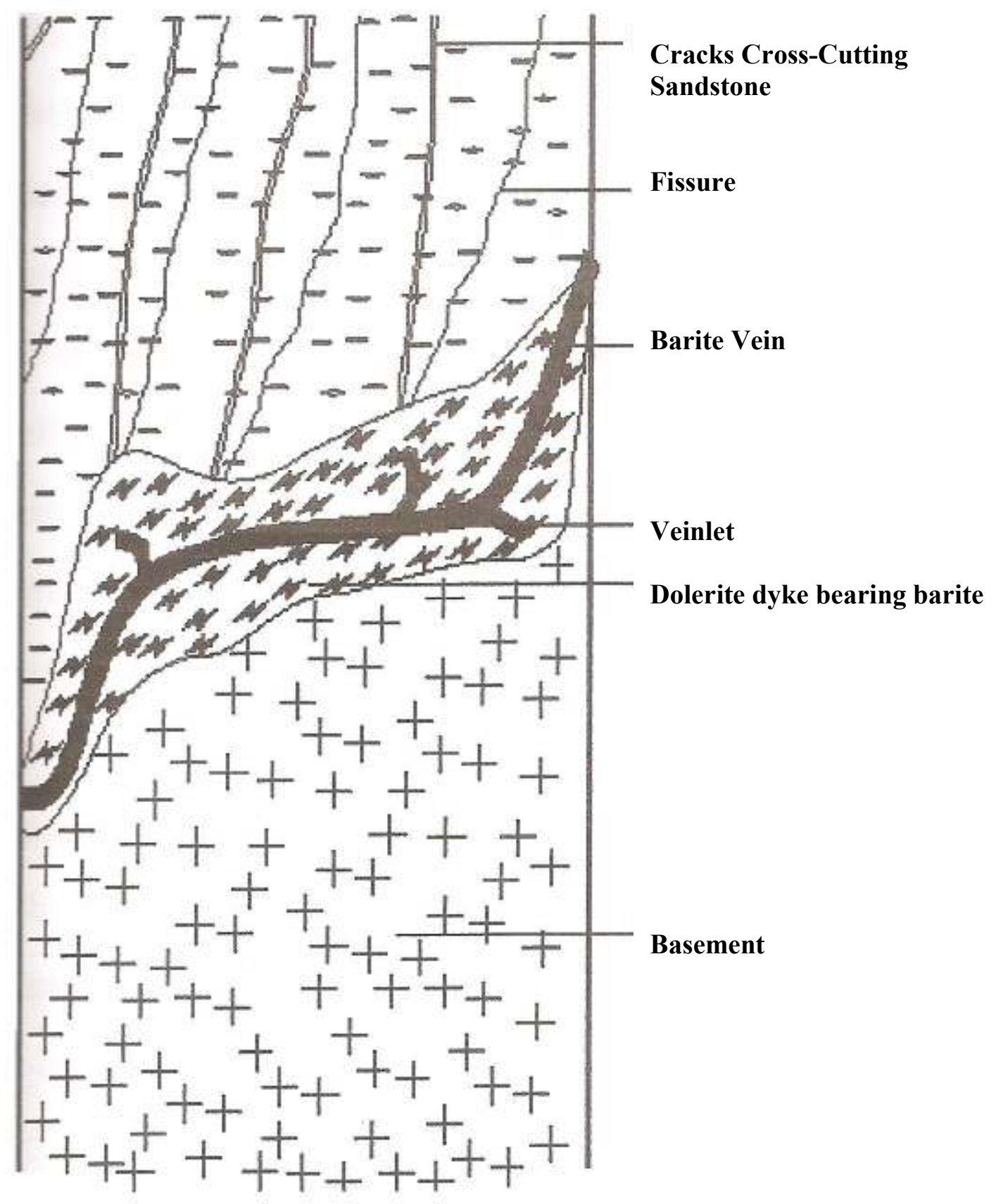

Fig 4: Sketch of barite bearing dolerite dyke occupying the boundary between sandstone and basement at Okurike $\left(05^{\circ} 37^{1} 07^{\prime \prime} \mathrm{N}, 08^{\circ} 31^{\prime \prime} 25^{\prime \prime} \mathrm{E}\right)$ 


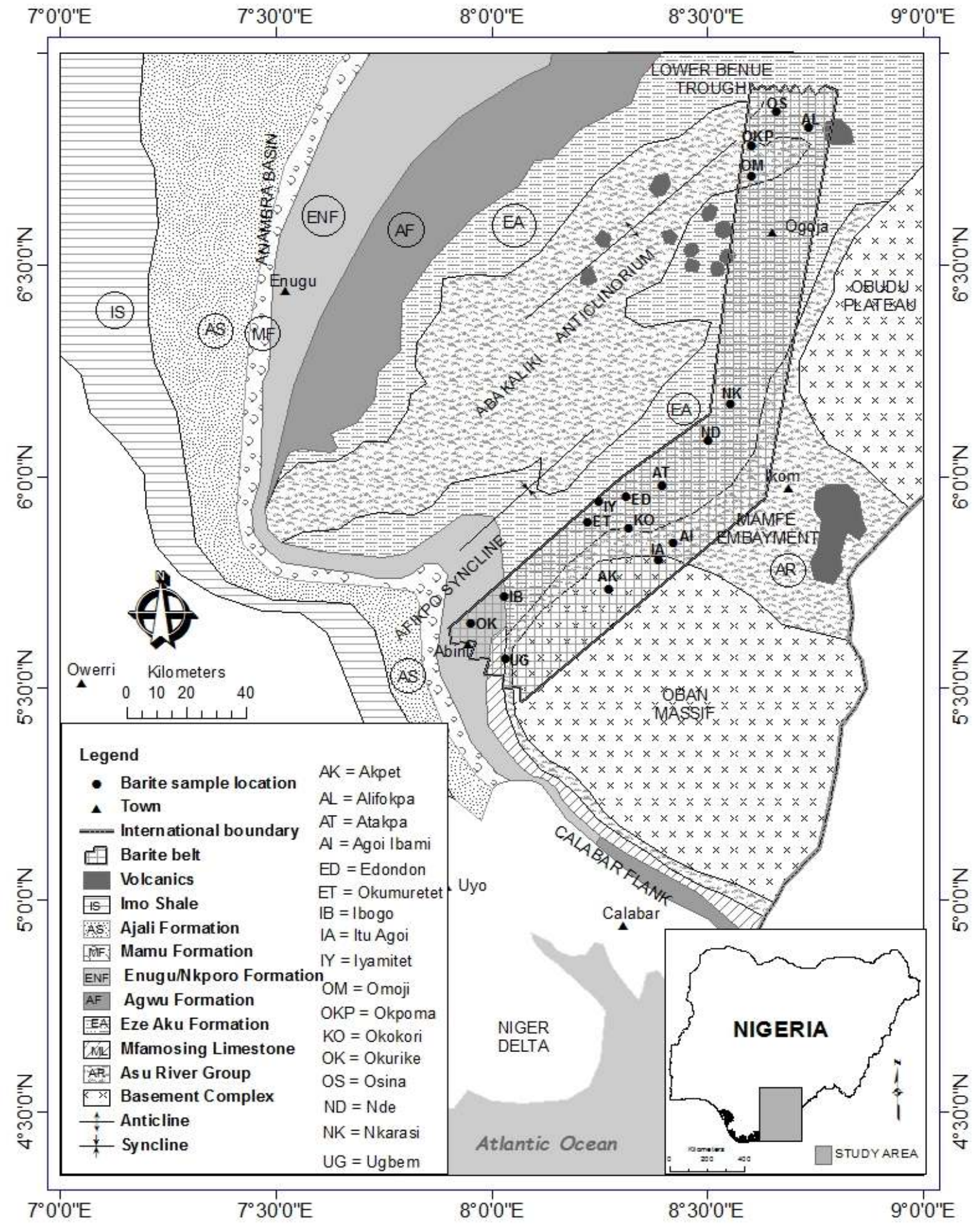

Fig 5: Map of barite mineralization zone in Cross River State (Modified after Ekwueme, 2003) 


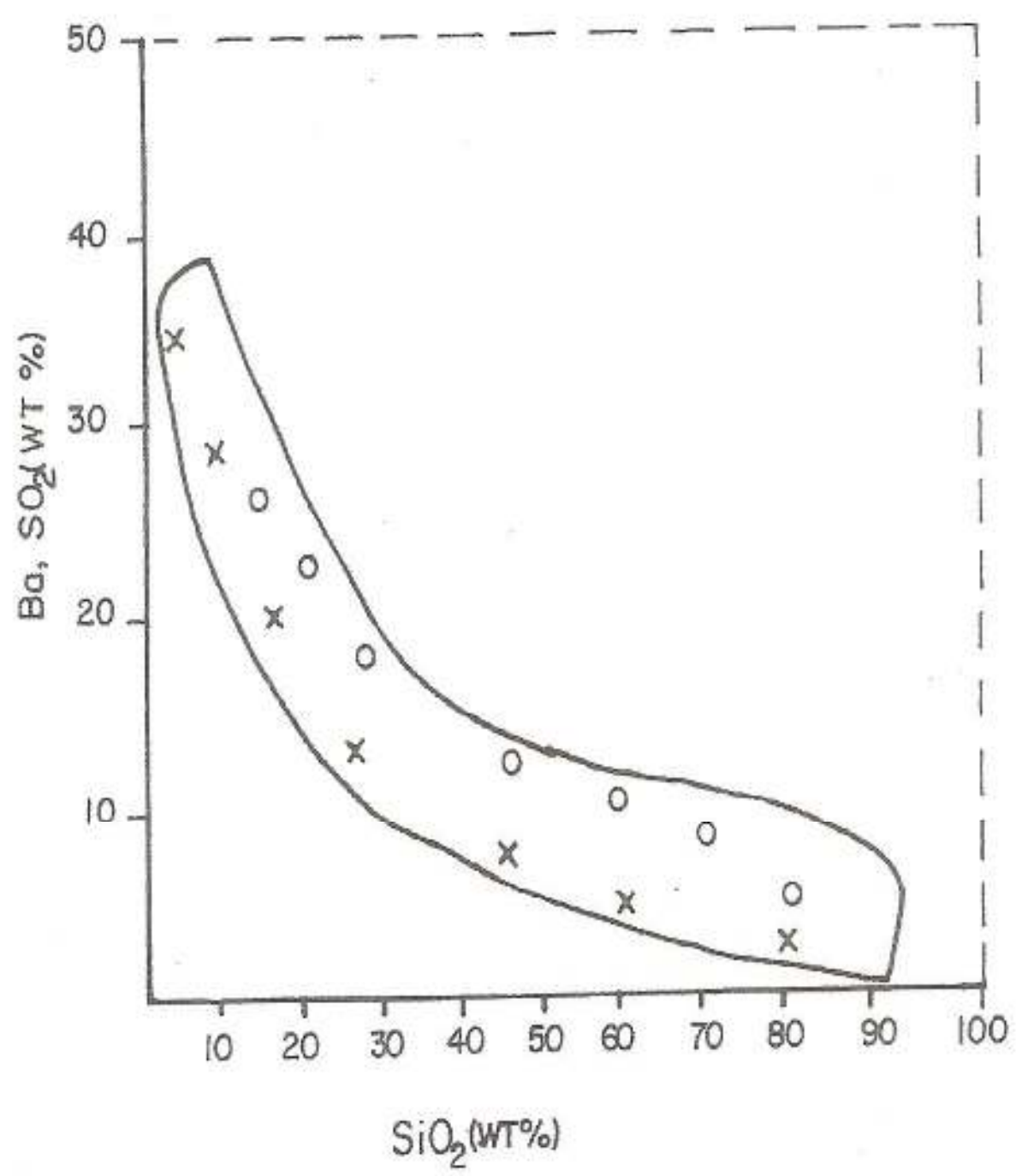

LEGEND

○ Ba

$\times \mathrm{SO}_{4}$

Fig 6: Plot of $\mathrm{Ba}$ and $\mathrm{SO}_{4}$ versus $\mathrm{SiO}_{2}$ for Rocks of Calabar Flank, Oban Massif, Mamfe Embayment and Obudu Plateau Southeastern Nigeria

\section{PETROGRAPHY}

Barite is a colourless mineral with one directional cleavage, moderate relief, high birefringence grey colour, and extinction angle of approximately $35^{\circ}$. It is often associated with gangue minerals such as quartz, calcite, biotite, chlorite and sulphides. The barite content in Itu Agoi samples is 92\%, while that of Okokori, Gabu and Agoi Ibiami samples are $87 \%, 94 \%$ and $86 \%$ respectively (Table 1). Associated gangue minerals in Itu Agoi samples include quartz, biotite and calcite.
Okokori samples have quartz and muscovite, while Gabu-Osina samples contain chlorite and biotite and needles of pyrite and chalcopyrite.

\section{CHEMICAL COMPOSITION AND INDUSTRIAL QUALITY}

In areas were barite mineralization was observed during geological mapping and sampling, a pair of samples of host rocks was collected at each site for possible variation in chemical contents. To ensure 
the evaluation of the industrial quality of barite occurrences in the study area, Cross River State has been divided into three geological zones.

Zone 1: Constitutes the southern part and places with economic barite occurrences are Akpet and Agoi areas. Here mineralization occurred within the sediments but dominantly at the boundary between basement and sediments. Typical host rocks here are phyllite, schist, gneiss, sandstone and siltstone (Table 2). This part belongs to the Calabar Flank/ Oban basement massif.

Zone 2: This is the central part of Cross River State. It falls within the Mamfe Embayment which is composed of Cretaceous sediments with basaltic flows in Ikom (Ekwueme 2012). The dominant rocks are sandstone and places with significant occurrences of barite include Okokori, Nsakwon, Atakpa, Nkarasi (Table 3).

Zone 3: This is the northern part of Cross River State. It is situated at Ogoja / Obudu Plateau and consists geologically of basement rocks overlain by the Asu River Group of Cretaceous age. Barite occurs dominantly in the Cretaceous sedimentary rocks but there are also occurrences at the boundary of the basement and sedimentary rocks. There are salt ponds in Okpoma. Rocks constituting the Obudu Plateau basement include, high-grade schists, gneisses, amphibolites, dolerite, pegmatites and granulites.

Table 2 shows the chemical composition of some host rocks. In zone 1 where barite occurs mainly at the basement/sediment boundary the typical basement rocks are phyllite, schist and gneiss. The chemical data show that barite content of the host rocks decreases with increasing $\mathrm{SiO}_{2}$ content (Fig. 6). For instance, in Akpet the $\mathrm{Ba}$ plus $\mathrm{SO}_{4}$ content is $8.6 \%$ whilst the $\mathrm{SiO}_{2}$ content is $85 \%$; in schist from Agoi Ibiami the $\mathrm{Ba}$ plus $\mathrm{SO}_{4}$ content is $20 \%$ whilst the $\mathrm{SiO}_{2}$ content is $46 \%$ and in the gneiss at lbogo Ba plus S04 is $15 \%$ whilst the $\mathrm{SiO}_{2}$ content is about $70 \%$. The schist in Itu Agoi is barren of barite and the $\mathrm{SiO}_{2}$ content is $64 \%$. A close examination of Table 3 which shows the chemical composition of barite samples indicates that the barite occurrences in Akpet, Agoi Ibiami, Ibogo and Itu Agoi are all of high quality with $\mathrm{Ba}$ plus $\mathrm{SO}_{4}$ content of $90 \%$ and above. There is no indication that the composition of the host rocks has effect on the quality of the barite. A close study of Table 3 shows that barite occurrences in the other two zones which are mostly within the sediments are also of high quality with $\mathrm{Ba}$ plus $\mathrm{SO}_{4}$ content of $90 \%$ and above, the only exception is the barite occurrence in Okurike in Zone 1 which is composed of sandstone. Barite occurrence in Okurike has very high $\mathrm{SiO}_{2}$ content of $73 \%$ compared with other occurrences in which $\mathrm{SiO}_{2}$ content is low (see Table 3). The barite in Okurike is of low quality having Ba plus $\mathrm{SO}_{4}$ content of only $18 \%$. It is most likely that the mineralization in the study area is independent of the host rock composition. The chemical composition of the barite is consistent with the modal composition (Table 2 ). It is possible that the mineralizing fluid of the barite is from other sources rather than from the host rocks. Previous studies of barite occurrences in the Benue Trough had pointed to evaporates as the source of the mineralizing fluids (Akande and Mucke 1989; Akande et al. 1989, 1992; Nwachukwu 1972). This is most likely the case for barites in the geological regions of Cross River State studied. An evidence of evaporates as the source is the rich salt ponds in Okpoma an area whose barite deposit has been sampled in this study. Mbipom et al. (1990) used the results of their resistivity survey in Okpoma area to suggest that even though the brine occurs at a depth of $20 \mathrm{~m}$, the source of the brine is deep-seated and possibly from compacted Shale or basement. The barite in Okpoma has $\mathrm{Ba}$ plus $\mathrm{SO}_{4}$ content of $86.6 \%$ (Table 3 ). The industrial quality of barite occurrences in the geological zones of Cross River State analyzed in this study is higher than that of the famous and well-known Azara barite deposits studied by Ajile (1989) and Bassey (1998) (Table 3). Oden (2012) noted that in the Benue Trough the quality of barite increases with depth of the veins. He observed that in most occurrences, the quality of the material from top part of a vein ( $0-5 \mathrm{~m}$ depth) is always lower than that from the deeper parts of the same vein. Hence, it is most likely that as mining gets deeper better quality barite can be obtained in this area. 
Table 1: Modal Composition of Associated Minerals of Barite-Bearing Samples in Calabar Flank, Oban massif, Mamfe Embayment and Obudu Plateau, Southeastern Nigeria

\begin{tabular}{|l|l|l|l|l|l|l|l|l|l|l|}
\hline MINERAL & OS & OM & GA & AT & NS & EK & AG & IA & AK & OK \\
\hline Barite & 96 & 86 & 94 & 95 & 93 & 87 & 86 & 92 & 90 & 20 \\
\hline Quartz & Tr & 8 & - & - & 2 & 9 & 10 & 2 & 4 & 71 \\
\hline Biotite & 2 & 1 & 2 & 1 & 1 & 1 & 4 & 3 & - & - \\
\hline Muscovite & $<1$ & 1 & 1 & $<1$ & $<1$ & 2 & - & - & 6 & 4 \\
\hline Calcite & 1 & $\mathrm{Tr}$ & $<1$ & $<1$ & $<1$ & 1 & $\mathrm{Tr}$ & 3 & - & 5 \\
\hline Chlorite & $<1$ & - & 2 & 2 & 3 & $<1$ & - & - & - & - \\
\hline Plagioclase & - & 4 & $<1$ & 1 & - & - & - & - & - & - \\
\hline Total & 100 & 100 & 100 & 100 & 100 & 100 & 100 & 100 & 100 & 100 \\
\hline
\end{tabular}

OS B: Barite-bearing sample from Osina

Om B: Barite-bearing sample from Omoji

Ga B: Barite-bearing sample from Gabu

At B: Barite-bearing sample from Atakpa

Ns B: Barite-bearing sample from Nsakwon

Ek B: Barite-bearing sample from Okokori

AG B: Barite-bearing sample from Agoi lbami

IA B: Barite-bearing sample from Itu Agoi

AK B: Barite-bearing sample from Akpet 1

OK B: Barite-bearing sample from Okurike 


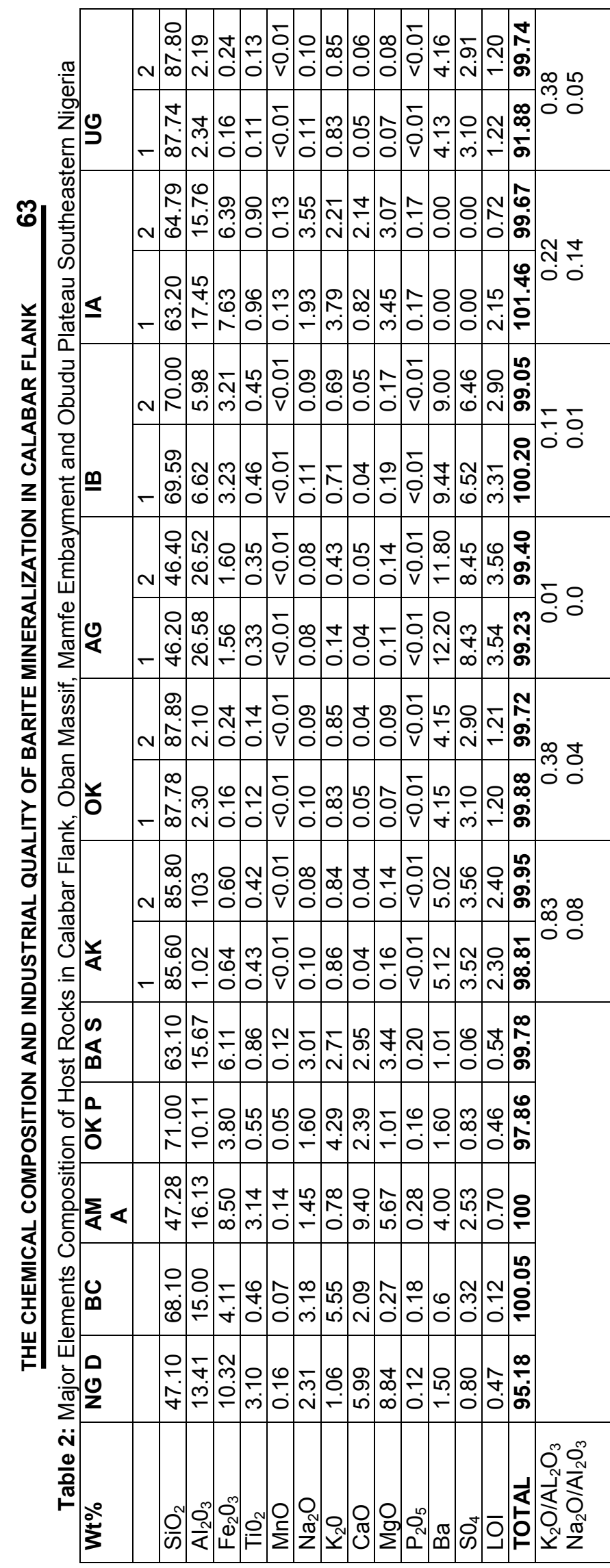

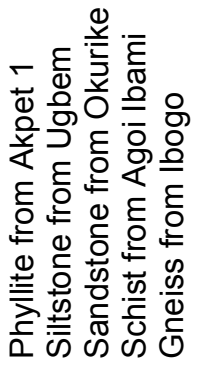

نั

$$
\begin{aligned}
& \text { ํํㅇ } \\
& \text { ह } \\
& 3
\end{aligned}
$$

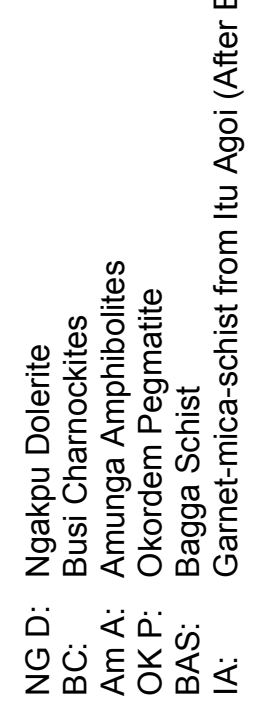



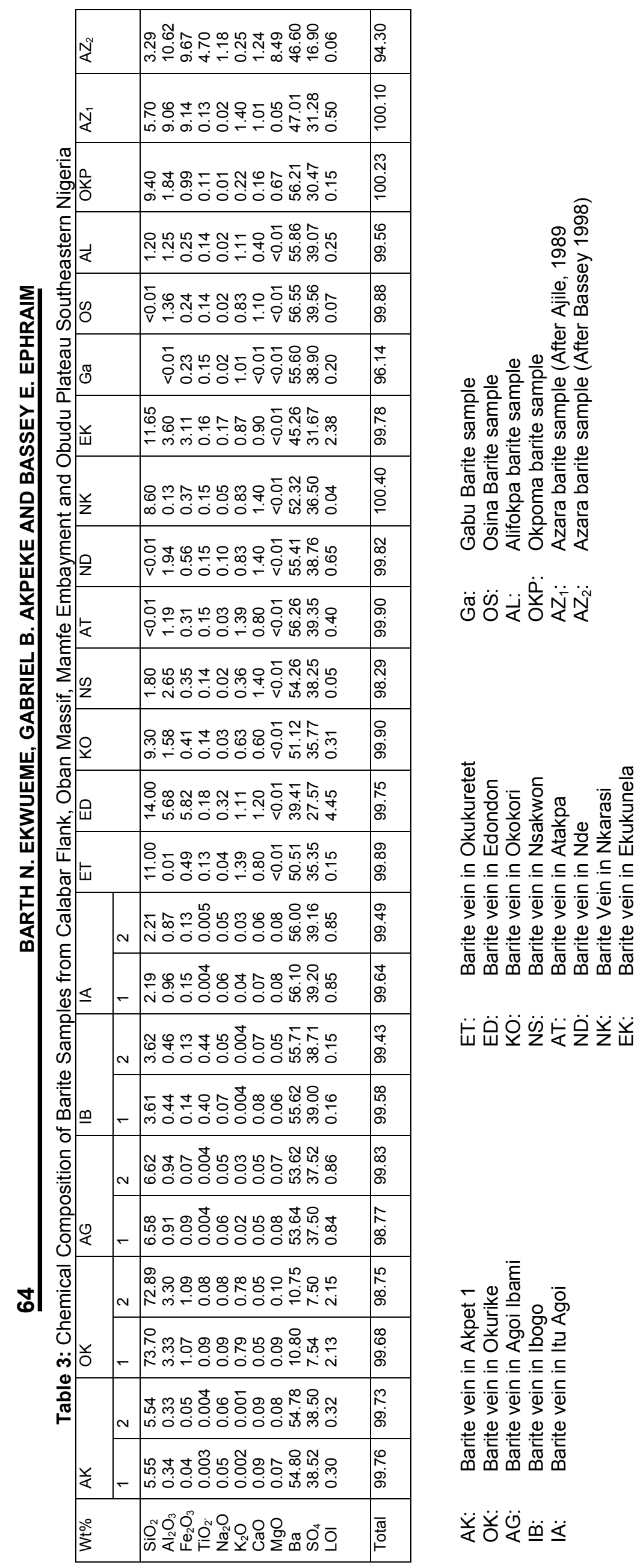

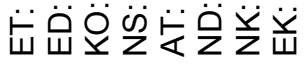

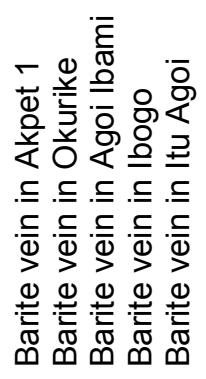

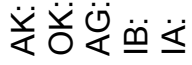




\section{CONCLUSION}

Barite occurs in basement/sediment boundaries marked by unconformities and faults in the Calabar Flank/Oban massif and Mamfe Embayment/Obudu Plateau as well as within sedimentary rocks of Cretaceous age in Cross River State of southeastern Nigeria. The chemical composition of the barite ores shows that they are of high industrial quality and suitable for use as weighting agent in drilling mud. The chemical compositions of the host rocks suggest that the source of the mineralizing fluids which facilitated the formation of the barite are evaporates as indicated by the occurrence of large salt ponds at Okpoma in the study area. This paper has therefore, established the geological and structural features that facilitated the emplacement of barite ores in Cross River State. It has also used geochemistry to characterize and determine the genesis of barite ores and their industrial quality.

\section{ACKNOWLEDGEMENTS}

This paper is a part of the Ph.D. Thesis project by GBA supervised by BNE. We are grateful to Professors Sam Akande, Victor Olarewaju and Eyo Ntekim for critical reviews which greatly improved the manuscript. George O. Essien typed the manuscript.

\section{REFERENCES}

Adeleye, D. R and Fayose, E. A., 1978. Stratigraphy on the type selection of Awi formation, Odukpani area, Southeastern Nigeria. Nigerian J. Min. Geol. 15:35-37.

Ajile, A. I., 1989. Mineralization, mining and beneficiation of Azara barite. Unpubl. B.Sc. Thesis, Univ. Jos, Nigeria.

Akande, S. O and Mucke, O., 1989. Mineralogical, Textural and Paragenetic studies of the LeadZinc-Copper mineralization in the lower Benue Trough (Nigeria) and their genetic implication. J. Afr, Earth Sci. 9, (1): 23-29.

Akande, S. O., Zentelli, M and Regnolds, P. H., 1989. Fluid inclusion and Stable Isotope studies of $\mathrm{Pb}$ $\mathrm{Zn}$-fluorite-barite mineralization in the lower and middle Benue Trough, Nigeria. Mineral. Deposita, (24): 183-191.

Akande, S. O., Andreas, A and Berndu, E., 1992. Environment of ore formation and Anchizonal metamorphism in $\mathrm{Pb}-\mathrm{Zn}$ fluorite-barite deposits of the Benue Trough, Nigeria. Geol. Mijnb. (71): 131-144.

Bassey, N. E., 1998. Aeromagnetic interpretation of Obudu and Environ. Unpubli. M.Sc. Thesis, Univ. Calabar, 46.

Benkhelil, J., 1987. Cretaceous deformation, magmatism and metamorphism in the lower Benue Trough, Nigeria. Geol. J., (22): 467-493.
Ekwueme, B. N., 1987. Structural orientation and Precambrian deformational episodes of Uwet area, Oban massif, SE Nigeria. Precamb. Res; (31): 269-289.

Ekwueme, B. N., 1994a. Basaltic magmatism related to the early stages of rifting along the Benue Trough: the Obudu dolerite of southeastern Nigeria. Geol. J., (29): 269-276.

Ekwueme, B. N., 1994b. Structural features of southern Obudu Plateau, Bamenda massif, southeastern Nigeria. Preliminary Interpretations. J. Min. Geol 30, (1): 45-59.

Ekwueme, B. N., 2012. An Easy Approach to Igneous Petrology. $2^{\text {nd }}$ edition. Univ. Calabar Press, 185.

Ekwueme, B. $\mathrm{N}$ and Kroener, A., 1997. Zircon evaporation ages and chemical composition of migmatitic schist in the Obudu Plateau: evidence of palaeoproterozoic (ca. 1789Ma) event in the basement complex of southeastern Nigeria. J. Min. Geol 33, (2): 81-88.

Ekwueme, B. N and Kroener, A., 1998. Single zircon evaporation ages from the Oban massif, Southeastern Nigeria. J. Afr. Earth Sci. 26, (2): 195-205.

Ekwueme, B. N and Kroener, A., 2006. Single zircon ages of migmatitic gneisses and granulites in the Obudu Plateau: Timing of granulite-facies metamorphism in southeastern Nigeria. Journal of African Earth Sci. 44, 459-4692.

Ekwueme, B. N., Nyong, E. E and Petters, S. W., 1995. Geological Excursion Guidebook to Oban Massif, Mamfe Embayment and Calabar Flank, Southeastern Nigeria. Sec-Ford Publishers Ltd. Calabar, Nigeria, 36P.

Kalsbeek, F., Ekwueme, B. N., Penaye, J., Souza, Z. S and Thrane, k., 2013. Recognition of Early and late Neoproterozoic supracrustal units in West Africa and Northeast Brazil from detrital zircon geochronology. Precamb. Res. 226, 105-115.

Krauskopf, K. B and Beiser, A., 1986. The physical Universe. McGraw - Hill, New York.

Mbipom, E. W., Okon-Umoren, O. E and Umoh, J. U.,

1990. Geophysical investigations of salt ponds in Okpoma area of southeastern Nigeria. J. Min. Geol. 26, (2): 285-290.

Nwachukwu, S. O., 1972. The Tectonic Evolution of the Southern portion of the Benue Trough, Nigeria. Geol. Mag. 109: $411-419$.

Oden, M. I., 2012. Barite veins in the Benue Trough: Field characteristics, the quality issues and 
some tectonic implications. Environmental and Natural Resources Research, 2, (2): 21-31.

Onyeagocha, A. C and Ekwueme, B. N., 1982. The PrePan-African structural features of North-Central Nigeria. Nigerian J. Min. Geol 19, (2): 74-77.

Petters, S. W., 1982. Central West African Cretaceous Tertiary Benthic Foraminifera and Stratigraphy. Palaeontographic A179: 1-104.

Petters, S. W., Okereke, C. S and Nwajide, C. S., 1987. Geology of the Mamfe Rift, S. E. Nigeria. In: G. Matheis and H. S. Schandelmeier (Editor), Current Research in African Earth Sci. Balkema, Rotterdam, 299-302.

Petters, S. W., Zaborski, P. M. P., Essien, N. U., Nwokocha, K. D and Inyang, D., 2010. Geological Excursion Guidebook to the Cretaceous of the Calabar Flank, SE. Nigeria, 28.

Reyment, R. A., 1965. Aspects of the geology of Nigeria. Ibadan Univ. Press, Ibadan, Nigeria, 145. 